\title{
Reengineering Government Process of Elections by Introducing Unemployed Ad Hoc Work Force Registered through Employment Exchanges in India
}

\author{
Reena M. Tak, Ph. D \\ Assistant Professor, MCA \\ Jawaharlal Institute Of Technology,Borawan \\ Khargone, Madhya Pradesh \\ India
}

\begin{abstract}
In India, Union general elections are held every five years. Likewise state assembly elections, municipal, Panchayat and Mandi elections are held separately at different times. In above activities, apart from the core group of the relevant government department, the services of a large number of personnel from other departments are utilized. On the one hand, their departmental activities suffer due to absence from their regular workplace and on the other hand, since the skills of these persons are not suited to this type of job, they generally resent and resist performing these duties. At the same time the country has a large number of unemployed youth registered in employment exchanges. This paper makes a proposal on the basis of a survey that: at the time of registration in the employment exchange, the registrant should be asked to confirm whether he would volunteer for such duties on payment of suitable remuneration. This solution will partly solve the problem of arranging a large work force for elections and partly the problem of unemployment for young people seeking job opportunities.
\end{abstract}

\section{General Terms}

Registered Candidates, Ad hoc Work Force, Honorarium, Training, Employee

\section{Keywords}

Elections, Employment Exchange, E-Governance, BPRE.

\section{INTRODUCTION}

Elections are the most important "festival" of democracy. Since independence, elections in India have evolved a long way, but all along elections have been a significant cultural aspect of independent India. In 2004, Indian elections covered an electorate larger than 670 million people-over twice that of the next largest, the European Parliament elections - and declared expenditure has trebled since 1989 to almost $\$ 300$ million, using more than 1 million electronic voting machines. In 2009, the elections covered an even larger electorate of 714 million (larger than both EU and US elections combined).

Due to large size of the democracy and huge list of voters, the elections in India are conducted in a number of phases (there were four phases in 2004 General Elections and five phases in 2009). It involves a number of step-by-step processes from announcement of election dates by the Election Commission of India, which brings into force the 'model code of conduct' for the political parties, to the announcement of results and submission of the list of successful candidates to the executive head of the state or the centre. The submission of results mark the end of the election process, thereby paving way for the formation of the new government.

\section{EMPLOYMENT EXCHANGES IN INDIA:}

The employment service came into existence in India under the stress of post war demobilization. Towards the end of the Second World War, the need for machinery which could handle orderly re-absorption of civil life, of a large number of service personnel and war workers was keenly felt.

In order to ensure uniformity in policies and effective coordination of efforts, the Directorate General of Resettlement and Employment (DGR \& E) was set up in July 1945 and employment exchanges were gradually opened in several parts of the country.[1]

In the year 1948, employment exchanges were opened to all categories of applicants. This transition of the employment service from a resettlement agency to an all India Placement organization resulted in an enormous increase in work.

Several committees were set up to review and redesign the structure of employment exchanges. These initiatives of central government also direct state government and its agencies to provide services to more and more number of candidates. So, different types of services were started in a decentralized manner to cater candidates from all parts of the country. District employment exchanges are one such link in the whole chain to provide services at district level. It also controls other institutes at different levels of the district.

\subsection{ROLE OF EMPLOYMENT EXCHANGE:}

Initially employment exchanges were the sole authority in recruitment of candidates but with the development and establishment of new recruitment boards, panchayati raj system with authority to recruit through panchayati institutions, cut down of posts in different sectors results in reduction of recruitments through employment exchanges. In the year 1995-96, Supreme Court of India has given a decision according to which if any organization is recruiting through employment exchanges then it is necessary to advertise that vacancy in at least two local news papers/ radio etc. to invite applications from candidates. This results in 
direct recruitments through news paper advertisement by organization instead of forwarding the vacancy through employment exchanges. All the above mention reasons contributed to the decreasing popularity and importance of employment exchanges.

But as unemployment is a big problem in India, employment exchanges have started various schemes to attract more and more candidates and provide guidance and training to them to acquire jobs. Following initiatives of employment exchange are helping candidates to get jobs:

- Job fair organized by employment exchanges to increase awareness

- Jobs in private sectors are also given importance

- Career counseling by one psychologist

- Three subject specialists are also provided to candidates for guidance.

- To increase awareness for selection of proper career, employment exchanges are organizing job fairs, career camps and discussions (vaarta) regularly.

\subsection{SIGNIFICANCE OF EMPLOYMENT EXCHANGES:}

Employment exchanges in India have been designed with great care and concern to cater the needs of big percentage of unemployed youth. Working mechanisms of these employment exchanges have been appreciated for their impartial treatment and efficiency. Following are the major steps that they take for the benefits of young people who are registered under this government organization:

- Attracting candidates from rural areas also to get jobs in both public and private sectors.

- Evaluation of vacancies.

- Helps in career development.

- Impartial service: 12 names are forwarded against one post in the order of seniority of candidates registered.

\subsection{DISTRICT EMPLOYMENT EXCHANGE KHARGONE:}

Khargone is a district of state of Madhya Pradesh of India. This district belongs to the category of rural and tribal population. Here government has started penetrating to different sections of the society so as to provide basic amenities to downtrodden and under developed citizens. Here, government organizations are working hard to educate the population and helping them to get good job opportunities. Considering this status of the district, the author has started surveying not only the employment exchange but also the rural population. During this effort, the author found following important characteristics of the employment exchange of Khargone:

Total registered candidates in district employment exchange khargone are 38,900. The employment exchange offers different types of jobs, like: peon, clerk, teacher, sweeper, driver, fitter, electrician, wireman, surveyor, computer operator, watchman etc. Employment exchange forwards 12 names in seniority of candidates against one post. The employment exchange plays an important role towards the recruitment and job offers of the candidates and hence every year approximate $35-40 \%$ candidates come for renewal of their registration.

\section{PRESENT WORKING MODEL FOR CONDUCT OF ELECTIONS \& GETTING THE REQUIRED WORK FORCE}

Indian elections are reputed world wide as a wonderful manifestation of both the administrative competence and sagacity of the electorate in ensuring fair and free exercise of franchise under very tough circumstances.

A very big contingent of employees from government and semi government organization work sincerely and diligently for a fairly long period to ensure success of the electoral process.

However, this also leads to disruption of activities of the parent organization of these "volunteers". The parent organization is no doubt engaged in nation building activities, almost as important as elections, while they subjugate their primary priorities to elections. However, is it right to disrupt activities like school and higher education which is a priority area? The problem assumes more importance as the numbers of elections (Centre, State, Local, Mandi etc.) get desynchronized. Taken together they engage the sizeable part of working year of these organizations.

There have been signs of discontentment among the employees who are commissioned for election duties and some have even gone through courts under various pretexts.

\section{PROPOSED MODEL}

\subsection{NEED OF BPRE}

In 1990, Michael Hammer, a former professor of computer science at the Massachusetts Institute of Technology (MIT), published an article in the Harvard Business Review, in which he claimed that the major challenge for managers is to obliterate forms of work that do not add value, rather than using technology for automating it. Hammer's claim was simple: Most of the work being done does not add any value for customers, and this work should be removed, not accelerated through automation. Instead, companies should reconsider their processes in order to maximize customer value, while minimizing the consumption of resources required for delivering their product or service. A similar idea was advocated by Thomas H. Davenport and J. Short in 1990,[2] at that time a member of the Ernst \& Young research center, in a paper published in the Sloan Management Review

As per the basic concepts of BPRE the need to reengineer the entire process was felt to achieve higher level of success and better performance with unexpected results.[3] This approach will help to redesign the entire system. Keeping in mind the fundamentals of BPRE the author proposes to reengineer the conduct of election process by fusing the registered but unemployed candidates of employment exchanges.

A literature survey in this field, extended with actual BPR experiences, has rendered 30 practices that are often applied in the redesign of a business process. BPR Practices are normally referred to as BPR heuristics. Mehdi Asgarkhani and Brad Patterson[4] summarized Business process reengineering 30 best practices into five large categories: 
- Task Rules: A focus on optimizing single tasks within a business process.

- Routing Rules: They try to improve upon the routing structure of the business process.

- Allocation Rules: Involve a particular allocation of resources to activities

- $\quad$ Resource Rules: focus on the types and availability of resources.

- Rules for external parties: They try to improve upon the collaboration and communication with clients and third parties involved in the process.

We can use these categories to identify the requirement of our process design for the existing system of electoral process. The idea of process reengineering seems like a good idea for business development for the future. Reworking the processes of a business to streamline work and cut costs brings benefits to business and saves time and budget. Extreme BPR seems like a good choice if the correct conditions arise. If the problem can be solved at one or more sections of the process or organization then it should be done in parts only. It is better to reengineer in parts than to go with reengineering the entire process. This would have to be decided after analyzing the processes. Business process re engineering is not downsizing, restructuring, reorganization, automation, new technology, etc. It is the examination and change of five components of the business Strategy, Processes, Technology, Organization and Culture.[5]

\subsection{NEED OF E-GOVERNANCE}

E-governance refers to governance processes in which Information and Communication Technology (ICT) play an active and significant role. E-Governance (from electronic governance, also known as e-gov, digital governance, online governance or in certain context transformational governance) refers to government's use of information technology to exchange information and services with citizens, businesses, and other arms of government.[6]

E-Governance is widely accepted as an effective tool of service delivery and equated with Good Governance by all developed countries in general and developing countries like India in particular. Information and Communication technologies are developing faster than ever before and these aid the process of development and good governance.[7]

When the need of BPRE is felt, we simply cannot ignore the concept of e-governance. The reengineering of the entire procedure includes the usage of information and communication technology tools to make an effective network. This will motivate not only the government organizations but also the candidate to be in constant touch with each other. Such network may result in better services with more availability and reliability of the work force.

\subsection{REENGINEERED PROCESS FOR CONDUCT OF ELECTIONS AND ADHOC SERVICES FOR UNEMPLOYED YOUTH}

The author proposes a viable alternative to provide electoral workforce which will lead to a "win-win" situation.

The employment exchange in every district maintains an active list of youth available for meaningful work. This pool can be tapped for work during election process. The volunteers can be given reasonable honorarium. They can also be monitored for their efficiency and those who exhibit excellent working skills can be offered a lateral entry in the district administration.

For this model to work, every registrant, while applying for registration in the employment exchange, would have to exercise a choice of whether he wants to volunteer for election duties. If he does, he will have to furnish a reference of some person employed in government/semi-government organization who could guarantee his reliability for such work.

The training being imparted at present to employees engaged in election duty can be given to these unemployed youth. Then they can be effective in performing these duties.

To have an idea of interest of registered candidates of employment exchanges for the above mentioned proposal, the author did a non experimental survey based study on registered candidates of employment exchange of Khargone district.

\section{PURPOSE OF THE STUDY:}

The major objective of this non experimental study was to identify the view of unemployed youth towards getting some jobs on ad hoc basis which may include some sort of training to perform important government duties and getting honorarium for the same. The study was focused on determining the perception of unemployed youth of different levels of academic qualifications from different section of the society.

\section{SETTING AND SAMPLE:}

To conduct this non-experimental survey based study, the author chosen a sample from district employment exchange Khargone (M.P.). This employment exchange contains a variety of candidates registered under different categories, depending upon their educational qualifications. Both male and female candidates of different age groups were chosen in random order that have different academic, social and financial backgrounds. These registered unemployed youth participated in the survey with great enthusiasm and hence contributed towards the achievement of a revolutionary idea.

\section{SURVEY RESULT OF REGISTERED CANDIDATES OF EMPLOYMENT EXCHANGE FOR GOVERNMENT DUTIES}

Total Candidates Surveyed:

Total Yes:

18

Total No:

21

Total No Response:
04 


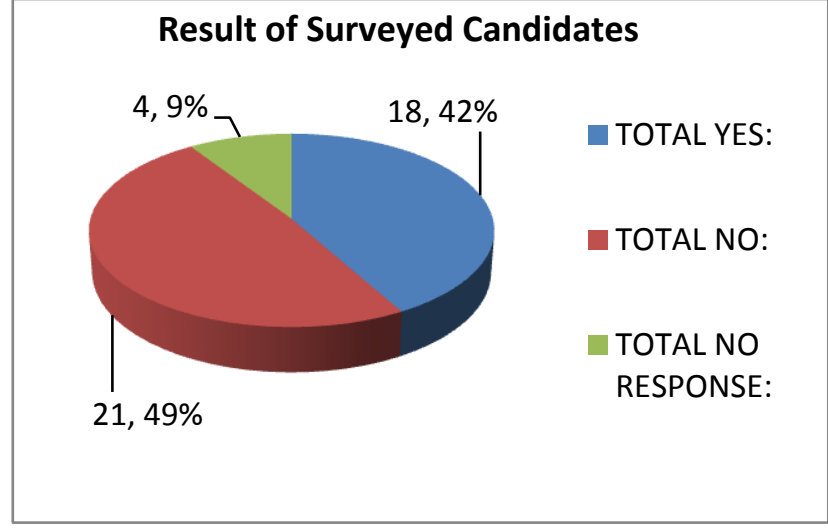

Fig 1: Graph showing the survey result

Total registered candidates in employment exchange: 38900

Total candidates willing to do government duties : 16338

Total workforce needed for elections $1200 * 4=$ 4800

\section{IMPLICATIONS OF THE STUDY}

As the author has studied the result of the survey, it was found that there are total 38,900 candidates registered in employment exchange of Khargone district. From this large set of unemployed youth, 42\% (16338) are interested in serving as volunteers for the government agencies for different duties, election among them. As per the district collectorate of Khargone, there are total 1200 election booths and each requires 4 volunteers which comes to total 4800 volunteers. So, it is very clear that we have sufficient work force to perform these duties.

\section{RECOMMENDATIONS FOR ACTIONS TO IMPLEMENT THE PROPOSAL:}

The National E-governance Plan (NeGP) envisages several Mission Mode projects (MMPs) that use modern technology to simplify delivery of services to citizens. The success of these projects not only depends on the technology used but also on new or modified processes that overcome past inefficiencies and optimally use the new technology.[8]

The author proposes following steps to be executed for the implementation of the above mentioned idea:

\section{candidates:}

9.1 Creation of centralized database of interested

After studying the results of the survey conducted, the author came to a conclusion that this proposal could be implemented. The author suggests and recommends that employment exchanges should take details regarding candidate's interest for ad hoc duties and maintain a centralized database which could then be shared among different organizations to avail the services of this work force.
9.2 Establishment of e-kiosks and cyber centres to communicate with the candidates:

After creating the centralized database, it is necessary to have a communication channel between government agencies and unemployed registered candidates who are seeking good job oppurtunities. For the fulfillment of this objective, the author proposes to use e-kiosks and cyber centres along with other communicating devices like, telephone, mobile and internet services. desired task:

9.3 Supervision of trained officers suited to the

After preparing the work force, some trained officers should be appointed from the concerned departments, to supervise. employees:

9.4 Appropriate Training for the ad hoc

On occasions of elections and other such activities, this database could be used and candidates can be called. After training, they can then be forwarded to execute these duties. workforce:

9.5 Provision of remuneration for this

The success of this proposal is definitely being counted if proper remuneration is given to this unemployed work force.

\section{BENEFITS OF THE REENGINEERED SYSTEM:}

If the proposed model be implemented then the government will not only be providing jobs to a big percentage of unemployed youth but also be able to save other government departments from loss of work for the period of other duties. The advantages of the proposed model can be listed as follows:

- Work of parent organizations will not suffer.

- Proper utilization of workforce in different departments because employees will not be taken from their core departments and hence they can conduct their departmental activities.

- The cost of loss of work not being there, this will be a more economical model than the present one

- Better performance of young volunteers compared to unwilling middle aged employees

- A number of unemployed youth will have the satisfaction of being partially employed in a very respectable national activity

- Ready availability of a large group of volunteers conversant with government procedure that can be utilized in future for other activities

- With number of elections and other activities which may use them (census, awareness campaigns of the government) they will have a number of opportunities

- the average age of the election workforce will become much less, resulting in more efficiency

- some of these young person's will have the opportunity of lateral entry in district administration

- The administration will have the chance of employing pre-tested staff who has already proved their mettle in a very important activity like elections.

- Fairer election results because of neutral volunteers instead of committed government employees. 
To sum up it can be said that the proposed model will be a revolutionary idea to engage registered candidates of employment exchange and use them in productive work of government.

\section{FUTURE WORK:}

E-government success will mainly depend on the improvement obtained as a result of BPR implementation. Reaching higher e-government levels is related to business processes redesign to take advantage of IT capabilities. One portal working on front office to receive requests is not enough; government must now be prepared to provide quick and high quality services.[9] In context of this paper, the author wishes to continue the research for several different aspects of the proposal to present its effectiveness.

For the current paper, the author has limited her study to collect the opinion of the registered candidates for ad hoc jobs. This non experimental survey based study will definitely result in an optimistic solution. For future works, the author suggests that an attempt to estimate the expenses of the existing arrangements including losses to the parent government organizations can be done. This will be weighed against the expenses of the proposed arrangement. The analysis may lead to a scientific evaluation of the economic feasibility of the proposed system.

After having a complete understanding of the investments and the return and benefits, the authorities will have a clear vision to take decisions regarding implementation of this proposal.

\section{CONCLUSION:}

Via the examination of case study the author has seen how this ideological framework provides a number of advantages for the development of a new system. The interdepartmental and agency barriers are porous, thus allowing seamless collaboration across agencies. By implementing the above proposal, we can generate work force from fresh stuff there by presenting good opportunities rather than the replication of governmental structures behind the scenes.

Efficiency is at the core of the process. Structures are capable of being easily remodeled without fear of creating territorial resentment within agencies [10]. Within the structure of the administration, we can easily exchange not only information but also the work force among these organizations. Benefits can be easily marked with the introduction of new methodologies in the system with a fusion of BPRE and egovernance.

The survey conducted and the study with respect to the above said problem will definitely, partially solve the problem of acquiring the required work force for elections and partially solve the unemployment problem. The proposed model and its implementation will be beneficial on many grounds. The author suggested the reengineering of the entire system of election process and many other activities and this approach will help to redesign the entire system.

\section{ACKNOWLEDGMENTS}

The author wishes to thank Mr. R. K. Anand, Retd.-Head Computer Centre, RDVV, Jabalpur, for his help in developing the concept which emerged during discussions with him. MS Excel is the Intellectual property of Microsoft. The author is thankful to Computer Centre RDVV for providing the official version of this software for analyses.

\section{REFERENCES}

[1] NATIONAL EMPLOYMENT SERVICE MANUAL, VOLUME- I (1 - 10)Government of India, Ministry of Labor \& Employment, Directorate General of Employment \& Training New Delhi.

[2] Thomas H. Davenport and J. Short, THE NEW INDUSTRIAL ENGINEERING: INFORMATION TECHNOLOGY AND BUSINESS PROCESS REDESIGN Published in Sloan Management Review, Summer 1990, Vol. 31, No. 4.

[3] Business Process Re-engineering Assessment Guide, United States General Accounting Office, May 1997.Available http://en.wikipedia.org/wiki/Business_process_reenginee ring

[4] Report on business Process Reengineering for egovernance projects, Department of Administrative Reforms \& Public Grievances Ministry of Personnel, Public Grievances and Pensions Government of India.

[5] Mehdi Asgarkhani and Brad Patterson,"Information and Business Process Re-engineering through Application of Information and Communication Technologies", International Conference on Recent Trends in Computer and Information Engineering (ICRTCIE'2012) April 1315, 2012 Pattaya.

[6] Jeong Chun Hai @Ibrahim. (2007). Fundamental of Development Administration. Selangor: Scholar Press. ISBN 978-967-5-04508-0Available at: https://en.wikipedia.org/wiki/E-Government

[7] B. R. Prasannakumar: "E-Governance and Service Delivery- Scope and Implementation Issues", Network of Asia PacificSchools and Institutes of Public Administration and Governance (NAPSIPAG). [Online] Available: http://www.napsipag.org/pdf/BR_PRASANNAKUMAR. pdf (2013)

[8] Government Process Architecting Framework (GPAF), Department of Administrative Reforms and Public Grievances (DAR\&PG), Govt. Of India May, 2012

[9] Kieron O'Hara \& David Stevens,'Democracy, Ideology and Process Re-Engineering: Realising the Benefits of eGovernment in Singapore", available at http://www.w3c.org.hk/www2006/papers/re-eng_sg.pdf

[10] Rodrigo L. Martín and Jorge M. Montagna, "Business Process Reengineering Role in Electronic Government", available at http://sedici.unlp.edu.ar/bitstream/handle/10915/24431/D ocumento_completo.pdf 